\section{Spore Release in Peronospora tabacina Adam.}

DOWNY mildew or blue mould of tobacco caused by Peronospora tabacina Adam. is destructive in the American and Australian regions and has now been reported for the first time in Europe ${ }^{1}$. It survives in association with over-wintering or over-summering host plants of which infected $N$. tabacum is of major importance ${ }^{2,3}$. Such plants produce conidia that are airborne and can establish infection in distant areas ${ }^{2}$.

De Bary suggested that dissemination of conidia of Phytophthora infestans (Mont.) de B. was brought about by changes in humidity causing violent movement of conidiophores and conidia were "thrown off in every direction"'. Ingold ${ }^{5}$ did not agree with de Bary's conclusion; but Pinckard ${ }^{6}$, working with Peronospora tabacina, supported it and also reported "ejection of sporangia (conidia) from their sterigmata by energy applied at the point of sporangial attachment". Hirst" concluded that sporangia (of $P$. infestans) were not removed by wet or dry gales but were dislodged by wetting, rapid changes in relative humidity and strong light. All investigators associated conidiophore movement with an increasing or decreasing relative humidity and spore dissemination with decreasing humidity. Cruickshank ${ }^{8}$ reported intensity of spore discharge in P. tabacina with change in relative humidity and mechanical shock. In the experiments reported here, factors other than ambient relative humidity were also concerned in spore release.

Dissemination of conidia was investigated at Canberra, Australia, with the aid of a spore trap ${ }^{9}$ operated among tobacco plants showing heavy sporulation. In three seasons of field experiments, the number of conidia trapped each hour of the day increased to a maximum between 0930 and $1100 \mathrm{hr}$. for periods of 12-16 consecutive days. This daily eycle was not interrupted by overnight relative humidity too low for sporulation, the conidia disseminated having been produced at an earlier date. Thus spore release was not conditional on a decreasing humidity being preceded by overnight saturation. This conclusion was confirmed by glasshouse tests in which the relative humidity subsequent to sporulation was maintained at low levels for long periods (Table 1

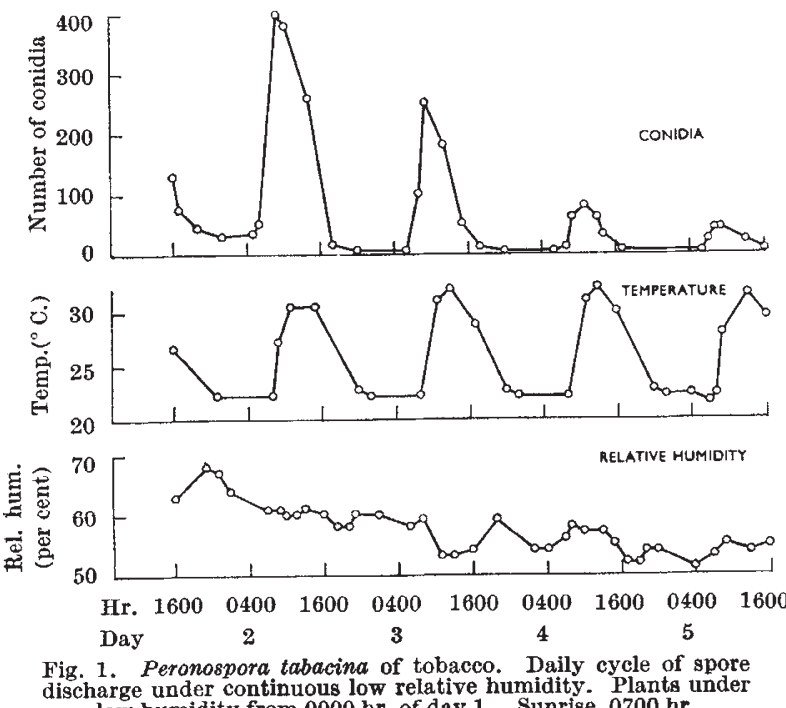

Fig. 1. Peronospora tabacina of tobacco. Dumidy. Plants under low humidity from $0900 \mathrm{hr}$, of day 1 . Sunrise, $0700 \mathrm{hr}$.

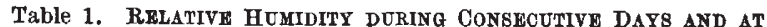
TIMES WHEN NUMBERS OF CONIDIA TRAPPED WERE INCRRASING

\begin{tabular}{|c|c|c|c|c|}
\hline \multirow[b]{2}{*}{$\begin{array}{c}\text { Time of rise in } \\
\text { numbers of } \\
\text { conidia trapped } \\
\text { (hr.) }\end{array}$} & \multicolumn{3}{|c|}{ Relative humidity (per cent)* } & \multirow[b]{2}{*}{$\begin{array}{l}\text { Period of test } \\
\text { (consecutive } \\
\text { days) }\end{array}$} \\
\hline & $\begin{array}{l}\text { Means at } \\
\text { hours in } \\
\text { frst } \\
\text { column }\end{array}$ & $\begin{array}{l}\text { Actual } \\
\text { and mi } \\
\text { total } \\
\text { Max. }\end{array}$ & $\begin{array}{l}\text { ximum } \\
\text { od for } \\
\text { od of } \\
\text { Min. }\end{array}$ & \\
\hline $\begin{array}{l}0712-1300 \\
0712-1112 \\
0815-1045 \\
0745-1120 \\
0645-0930\end{array}$ & $\begin{array}{l}61 \cdot 8-63 \cdot 4 \\
57 \cdot 0-48 \cdot 2 \\
47 \cdot 5-42 \cdot 5 \\
51 \cdot 2-51 \cdot 0 \\
57 \cdot 5-57 \cdot 2\end{array}$ & $\begin{array}{l}74 \\
79 \\
59 \\
60 \\
68\end{array}$ & $\begin{array}{l}55 \\
42 \\
37 \\
37 \\
51\end{array}$ & $\begin{array}{c}10 \dagger \\
5 \\
4 \\
4 \\
4+\end{array}$ \\
\hline
\end{tabular}

* From hygrographs among sporulating plants.

$\dagger$ Shaded glasshouse.
$\ddagger$ Also shown graphically.

and Fig. 1). The results of numerous tests show that the number of days in the daily cycle of spore release was least when there was a wide range, and repeated sudden fluctuations, in temperature and humidity. Daily periodicity for 4-10 days was common.

Examination of the fruiting structures of the pathogen in situ showed that twisting movements of the conidiophores were due to loss of turgidity in the stalk. This was followed by collapse of the branched superstructure, with many conidia still attached to it, on to the leaf surface. Spore release ceased but was resumed from both living and dead leaves on the same or succeeding days following periods of high ambient humidity. The spore trap data also showed that rising temperature, or light following a period of darkness, were associated with spore release. Collapsed conidiophores with attached conidia remained in that state, subsequent movements being restricted to some of the branches. The only method of spore dispersal that occurred either with or without conidiophore movement was, as described by Pinckard, due to "energy applied at the point of attachment".

These results show that spore release is regulated to provide for dissemination at intervals in time. Factors that appear to be responsible for spore release-reduction in relative humidity, increase in temperature, or light-could cause humidity or temperature-humidity changes in the region occupied by the conidiophores and thus ensure a progressive release of conidia. Whatever the mechanism involved, the results clearly show that spore discharge is a response to stimuli repeated at intervals, and that the normal interval was approximately $24 \mathrm{hr}$. Under this arrangement, conidia were held ready for dispersal and could take advantage of favourable conditions occurring at any time over a period of days following their production.

A full account of the work will be presented elsewhere.

Division of Plant Industry,

A. V. HrLr

Commonwealth Scientific and

Industrial Research Organization, Canberra.

1 "Seedborne Diseases of Tropical and Subtropical Crops", 8 (European and Mediterranean Plant Protection Organ., Jan. 1959).

2 McGrath, H., and Miller, P. R., Plant Dis. Rep., Supp. 250 (1958).

a Hill A. V., C.S.I.R.o. (Aust.) Div. of Plant Industry, Tech. Paper 9 (1957).

4 Waggoner, P. E., and Taylor, G. S., Phytopath., 48, 48 (1958).

Ingold, C. T., "Spore Discharge in Land Plants" (Oxford, 1939).

- Pinckard, J. A., Phytopath., 32, 505 (1942).

7 Hirst, J. M., Outlook on Agric., 2, 16 (1958).

Cruickshank, I. A. M., Aust. J. Biol. Sci., 11, 162 (1958).

'Hirst, J. M., Ann. App. Biol., 38, 257 (1952). 